\title{
Genetic Divergence Studies in Cowpea [Vigna unguiculata (L.) Walp.] Germplasm using Mahalanobis $D^{2}$ Analysis
}

\author{
Om Vir Singh*, Neelam Shekhawat, Kartar Singh and R. Gowthami \\ National Bureau of Plant Genetic Resources, Regional Station, Jodhpur-342 003, India \\ *Corresponding author
}

\begin{tabular}{|l|}
\hline Ke y w o r d s \\
Cowpea, Cluster, \\
$\begin{array}{l}\mathrm{D}^{2} \text { statistics, } \\
\text { Genetic Diversity }\end{array}$ \\
\hline Article Info \\
\hline $\begin{array}{l}\text { Accepted: } \\
\text { 24 February } 2018 \\
\text { Available Online: } \\
\text { 10 March } 2018\end{array}$ \\
\hline
\end{tabular}

\section{Introduction}

Among all the legume vegetable crops, cowpea [Vigna unguiculata (L.) Walp.] is grown as one of the most important vegetable crop in almost all parts of our country during rainy and summer season and has got potential to solve the protein problem. It is being cultivated in the drier parts of the world where other food legumes cannot withstand. This makes it the crop of choice for arid zone variability.
Thirty-eight accessions of cowpea were evaluated for nine quantitative characters to estimate the genetic diversity existing among them by using Mahalanobis $\mathrm{D}^{2}$ statistics during kharif2013 $\left(\mathrm{E}_{1}\right)$ and Kharif $2014\left(\mathrm{E}_{2}\right)$. The genotypes were grouped into ten clusters in $E_{1}$ and into five clusters in $E_{2}$ environment. In $E_{1}$ environment, the cluster strength varied from single genotype (Cluster III, IV, V VI, VIII, IX and X) to 16 genotypes (Cluster II), while in $\mathrm{E}_{2}$ environment, it varied from single genotype (Cluster III, IV and V) to 19 genotypes (cluster I). Clusters VII and X had highest inter-cluster distance in $\mathrm{E}_{1}$ and cluster II and III had highest inter-cluster distance in $\mathrm{E}_{2}$ environment. The maximum mean value for seed yield per plant, number of pods per plant and number of clusters per plant was showed by genotypes of clusters VII in $\mathrm{E}_{1}$ environment and by genotypes of cluster IV for the traits number of seeds per pod, pod length and plant height in $\mathrm{E}_{2}$ environment. On the basis of inter-cluster distances, cluster VII and X in $\mathrm{E}_{1}$ environment and cluster II and III in $\mathrm{E}_{2}$ environment were found to be most divergent. Cluster VII had the genotype with the highest mean value for number of seed yield per plant, number of pods per plant and number of clusters per plant in $\mathrm{E}_{1}$ environment, while cluster I had the genotypes which showed maximum mean value for seed yield per plant, number of pods per plant, peduncle length, and number of clusters per plant in $\mathrm{E}_{2}$ environment. Therefore, it was concluded that these clusters and their genotypes could be intercrossed in order to achieve more 
present study was taken up with an objective to estimate the genetic diversity for seed yield and its components in cowpea using Mahalanobis $\mathrm{D}^{2}$ statistics during kharif 2013 $\left(\mathrm{E}_{1}\right)$ and Kharif $2014\left(\mathrm{E}_{2}\right)$.

\section{Materials and Methods}

The present investigation was carried out with 38 accessions (Table 1) of cowpea germplasm collected from different agro climatic zones and conserved in the regional seed gene bank, ICAR- National Bureau of Plant Genetic Resources (NBPGR), Regional Station, Jodhpur. The experiment was conducted in randomized block design with three replications for two consecutive years (environments) viz., Kharif 2013 and kharif 2014, at Research field of NBPGR, Regional Station, Jodhpur, India, which is situated at about $28^{\circ} 35^{\prime} \mathrm{N}$, longitude of $70^{\circ} 18^{\prime} \mathrm{E}$ and an altitude of $226 \mathrm{~m}$ above mean sea level. The recommended agronomic packages of practices were followed during the experimental period. Data was recorded on five randomly selected plants from each replication of each accession for the nine quantitative characters $i$. $e$. seed yield per plant $(\mathrm{g}), 100$-seed weight $(\mathrm{g})$, number of seeds per pod, pod length $(\mathrm{cm})$, number of pods per plant, peduncle length $(\mathrm{cm})$, number of clusters per plant and plant height $(\mathrm{cm})$ as per the standard descriptors described for cowpea. The data for nine quantitative were statistically analyzed to study genetic diversity by Mahalanobis' $\mathrm{D}^{2}$ statistic as per Rao (1952).

\section{Results and Discussion}

The analysis of variance for individual characters revealed significant differences among genotypes in both the environments. Grouping of the genotypes was carried-out by following the Tocher's method (Rao, 1952) with the assumption that the genotypes within cluster have smaller $\mathrm{D}^{2}$-values among themselves than those from groups belonging to different clusters. In all, ten clusters in $E_{1}$ environment and five clusters in $E_{2}$ environments were formed from 38 genotypes (Figure 1 and 2). The composition of clusters for both the environments is given in Table 2. In $\mathrm{E}_{1}$ environment, cluster II was the largest cluster having 16 genotypes followed by the cluster I comprised of 11 genotypes and cluster IV was third largest which contained four genotypes. The cluster VI contained two genotypes. The clusters III, IV, V, VI, VIII, IX and $\mathrm{X}$ were solitary clusters with single genotypes. In $\mathrm{E}_{2}$ environment, largest cluster was cluster I containing 19 genotypes. The cluster II was the second largest having 16 genotypes. The clusters III, IV and V clusters were comprised of single genotypes only. Similarly 66 genotypes of cowpea were grouped into twenty three different clusters by Nagalakshmi et al., (2010), Suganthi et al., (2007) carried out similar type of genetic divergence study in 30 genotypes of cowpea and grouped them into 12 clusters using Tocher's method. The findings were also accordance with the genetic diversity studies carried out by Pandey (2007), Valarmathi et al., (2007), Dalsaniya et al., (2009), Brahmaiah et al., (2014), Sandeep et al., (2014), Vavilapalli et al., (2014), Aswathi et al., (2015), Chandrakar et al., (2016a) and Patel et al., (2017).

Inter and intra-cluster distances are shown in Table 3. In $\mathrm{E}_{1}$ environment, the maximum inter-cluster distance $(D=41.97)$ was found between cluster VII and $\mathrm{X}$, followed by that between VI and VII $(\mathrm{D}=40.84)$. The minimum inter-cluster distance was observed between cluster III and IV ( $\mathrm{D}=5.38)$. The intra-cluster distance (D) ranged from 9.01 (cluster VII) to 10.21 (cluster-II). The seven clusters (III, IV, $\mathrm{V}$, VI, VIII, IX and $\mathrm{X}$ ) contained single genotype each and therefore, their intra-cluster distances were zero. 
Table.1 List of 38 accessions of cowpea used for genetic diversity analysis

\begin{tabular}{|c|c|}
\hline S. No. & Name of the accessions \\
\hline 1. & IC-20664 \\
\hline 2. & IC-26024 \\
\hline 3. & IC-27573 \\
\hline 4. & IC-39856 \\
\hline 5. & IC-219640 \\
\hline 6. & IC-253271 \\
\hline 7. & IC-253276 \\
\hline 8. & C-738 \\
\hline 9. & C-797 \\
\hline 10. & C-863 \\
\hline 11. & C-915 \\
\hline 12. & C-951 \\
\hline 13. & C-956 \\
\hline 14. & C-967 \\
\hline 15. & C-993 \\
\hline 16. & C-1006 \\
\hline 17. & C-1013 \\
\hline 18. & C-1025 \\
\hline 19. & C-1045 \\
\hline 20. & C-1054 \\
\hline 21. & C-1063 \\
\hline 22. & C-1070 \\
\hline 23. & $C-1085$ \\
\hline 24. & C-1089 \\
\hline 25. & C-1101 \\
\hline 26. & C-1105 \\
\hline 27. & C-1107 \\
\hline 28. & C-1109 \\
\hline 29. & C-1116 \\
\hline 30. & C-1124 \\
\hline 31. & C-1126 \\
\hline 32. & C-1127 \\
\hline 33. & C-1133 \\
\hline 34. & C-1135 \\
\hline 35. & NS-24/8-2 \\
\hline 36. & V-585 \\
\hline 37. & FTC-27 \\
\hline 38. & GC-3 \\
\hline
\end{tabular}


Table.2 Grouping of 38 cowpea genotypes into different clusters based on nine quantitative characters

\begin{tabular}{|c|c|c|}
\hline \multicolumn{3}{|r|}{ Kharif 2013 ( $\mathbf{E}_{1}$ environment) } \\
\hline Cluster number & Number of genotypes & Name of the genotypes \\
\hline I & 11 & $\begin{array}{l}\text { IC-253271, C-1109, C-1006, IC-253276, C-967, C-1116, C-1089, C-863, C-1133, C- } \\
\text { 1013, FTC-27 }\end{array}$ \\
\hline$\overline{\text { II }}$ & 16 & $\begin{array}{l}\text { C-1045, C-1070, IC-20664, C-1063, GC-3,C-1105, C-1101, IC-27573, C-993, IC- } \\
\text { 39856, V-585,C-1135, C-1025, C-1107, C-956, C-797 }\end{array}$ \\
\hline $\mathbf{V}$ & 1 & C-738 \\
\hline VI & 1 & NS-24/8-2 \\
\hline VII & 4 & IC-219640, C-1127, C-1126, C-1085 \\
\hline VIII & 1 & C-1124 \\
\hline Cluster number & Number of genotypes & Name of the genotypes \\
\hline $\mathbf{I}$ & 19 & $\begin{array}{l}\text { IC-20664, C-1070, C-1045, C-1063, GC-3, V-585, C-993, C-1105,C-1025, C-1054, } \\
\text { C-1135, C-738, C-1107, C-797, C-1101, IC-27573, IC-39856, C-951, C-1089 }\end{array}$ \\
\hline II & 16 & $\begin{array}{l}\text { IC-253276, C-1006, C-967, C-1109, C-1116, IC-253271, C-1133, C-1126, C-1013, } \\
\text { FTC-27, IC-26024, C-1127, C-863, IC-219640, C-1085, C-1124 }\end{array}$ \\
\hline III & 1 & NS-24/8-2 \\
\hline IV & 1 & C-956 \\
\hline $\mathbf{V}$ & 1 & C-915 \\
\hline
\end{tabular}


Int.J.Curr.Microbiol.App.Sci (2018) 7(3): 2616-2624

Table.3 Inter and intra (diagonal) cluster average distance

Kharif 2013 ( $\mathbb{E}_{1}$ environment)

\begin{tabular}{|c|c|c|c|c|c|c|c|c|c|c|}
\hline Cluster & I & II & III & IV & $\mathbf{V}$ & VI & VII & VIII & IX & $\mathbf{X}$ \\
\hline I & 9.03 & 21.54 & 15.00 & 13.38 & 15.13 & 30.04 & 15.51 & 10.90 & 12.14 & 30.98 \\
\hline II & & 10.21 & 12.47 & 13.55 & 12.81 & 14.31 & 32.72 & 21.20 & 24.76 & 15.89 \\
\hline III & & & 0.00 & 5.38 & 5.68 & 18.72 & 24.68 & 12.93 & 19.14 & 21.69 \\
\hline IV & & & & 0.00 & 6.71 & 21.11 & 23.98 & 11.65 & 18.36 & 22.54 \\
\hline V & & & & & 0.00 & 21.00 & 25.21 & 12.72 & 21.39 & 20.29 \\
\hline VI & & & & & & 0.00 & 40.84 & 29.62 & 30.86 & 17.65 \\
\hline VII & & & & & & & 9.01 & 16.37 & 15.80 & 41.97 \\
\hline VIII & & & & & & & & 0.00 & 15.99 & 27.91 \\
\hline IX & & & & & & & & & 0.00 & 35.44 \\
\hline $\mathbf{X}$ & & & & & & & & & & 0.00 \\
\hline \multicolumn{11}{|c|}{ Kharif $2014\left(\mathrm{E}_{2}\right.$ environment) } \\
\hline Cluster & \multicolumn{2}{|c|}{$\mathbf{I}$} & \multicolumn{2}{|c|}{ II } & \multicolumn{2}{|c|}{ III } & \multicolumn{2}{|c|}{ IV } & \multicolumn{2}{|c|}{$\mathbf{V}$} \\
\hline I & \multicolumn{2}{|c|}{9.78} & \multicolumn{2}{|c|}{16.70} & \multicolumn{2}{|c|}{14.20} & \multicolumn{2}{|c|}{12.42} & \multicolumn{2}{|c|}{16.84} \\
\hline II & & & \multicolumn{2}{|c|}{8.69} & \multicolumn{2}{|c|}{26.18} & \multicolumn{2}{|c|}{17.63} & \multicolumn{2}{|c|}{25.83} \\
\hline III & & & & & \multicolumn{2}{|c|}{0.00} & \multicolumn{2}{|c|}{19.22} & \multicolumn{2}{|c|}{18.74} \\
\hline IV & & & & & & & \multicolumn{2}{|c|}{0.00} & \multicolumn{2}{|c|}{13.85} \\
\hline V & & & & & & & & & \multicolumn{2}{|c|}{0.00} \\
\hline
\end{tabular}


Table.4 Cluster means of nine quantitative characters in 38 cowpea genotypes

\begin{tabular}{|c|c|c|c|c|c|c|c|c|c|}
\hline \multicolumn{10}{|c|}{ Kharif 2013 ( $\mathbf{E}_{1}$ environment) } \\
\hline Cluster & SYP & SW & SPP & PL & PPP & PDL & $\mathbf{C P}$ & BP & PH \\
\hline I & 51.59 & 8.61 & 13.67 & 13.49 & 96.01 & 19.05 & 37.04 & 5.66 & 70.09 \\
\hline II & 40.20 & 9.91 & 13.85 & 13.68 & 51.79 & 18.67 & 20.13 & 4.35 & 79.88 \\
\hline III & 51.13 & 9.01 & 13.14 & 17.64 & 59.49 & 18.91 & 28.27 & 5.80 & 51.33 \\
\hline IV & 27.17 & 10.28 & 13.08 & 17.60 & 73.83 & 16.72 & 27.21 & 6.60 & 58.56 \\
\hline V & 51.26 & 7.96 & 13.32 & 15.61 & 61.24 & 14.39 & 29.22 & 6.57 & 35.72 \\
\hline VI & 11.79 & 10.92 & 15.35 & 15.14 & 25.73 & 27.08 & 10.55 & 2.57 & 40.89 \\
\hline VII & 60.11 & 8.35 & 13.79 & 14.65 & 107.50 & 21.03 & 51.60 & 5.73 & 74.31 \\
\hline VIII & 49.72 & 15.45 & 12.69 & 16.74 & 84.84 & 15.26 & 38.15 & 6.27 & 44.49 \\
\hline IX & 54.05 & 11.23 & 15.47 & 12.57 & 98.37 & 29.15 & 36.76 & 5.73 & 89.69 \\
\hline $\mathbf{X}$ & 34.67 & 18.43 & 14.85 & 13.06 & 34.45 & 10.46 & 14.27 & 2.87 & 60.84 \\
\hline \multicolumn{10}{|c|}{ Kharif 2014 ( $E_{2}$ environment) } \\
\hline Cluster & SYP & SW & SPP & PL & PPP & PDL & $\mathrm{CP}$ & BP & PH \\
\hline I & 51.59 & 8.61 & 13.67 & 13.49 & 96.01 & 19.05 & 37.04 & 5.66 & 70.09 \\
\hline II & 40.20 & 9.91 & 13.85 & 13.68 & 51.79 & 18.67 & 20.13 & 4.35 & 79.88 \\
\hline III & 51.13 & 9.01 & 13.14 & 17.64 & 59.49 & 18.91 & 28.27 & 5.80 & 51.33 \\
\hline IV & 27.17 & 10.28 & 13.08 & 17.60 & 73.83 & 16.72 & 27.21 & 6.60 & 58.56 \\
\hline V & 51.26 & 7.96 & 13.32 & 15.61 & 61.24 & 14.39 & 29.22 & 6.57 & 35.72 \\
\hline
\end{tabular}

$\mathrm{SYP}=$ Seed yield per plant $(\mathrm{g}), \mathrm{SW}=100$ seed weight $(\mathrm{g}), \mathrm{SPP}=$ Number of seeds per pod, $\mathrm{PL}=\mathrm{Pod}$ length $(\mathrm{cm}), \mathrm{PPP}=\mathrm{Number}$ of pods per plant, $\mathrm{PDL}=\mathrm{Peduncle}$ length $(\mathrm{cm}), \mathrm{CP}=$ Number of clusters per plant, $\mathrm{BP}=$ Number of branches per plant and $\mathrm{PH}=\mathrm{Plant}$ height $(\mathrm{cm})$ 


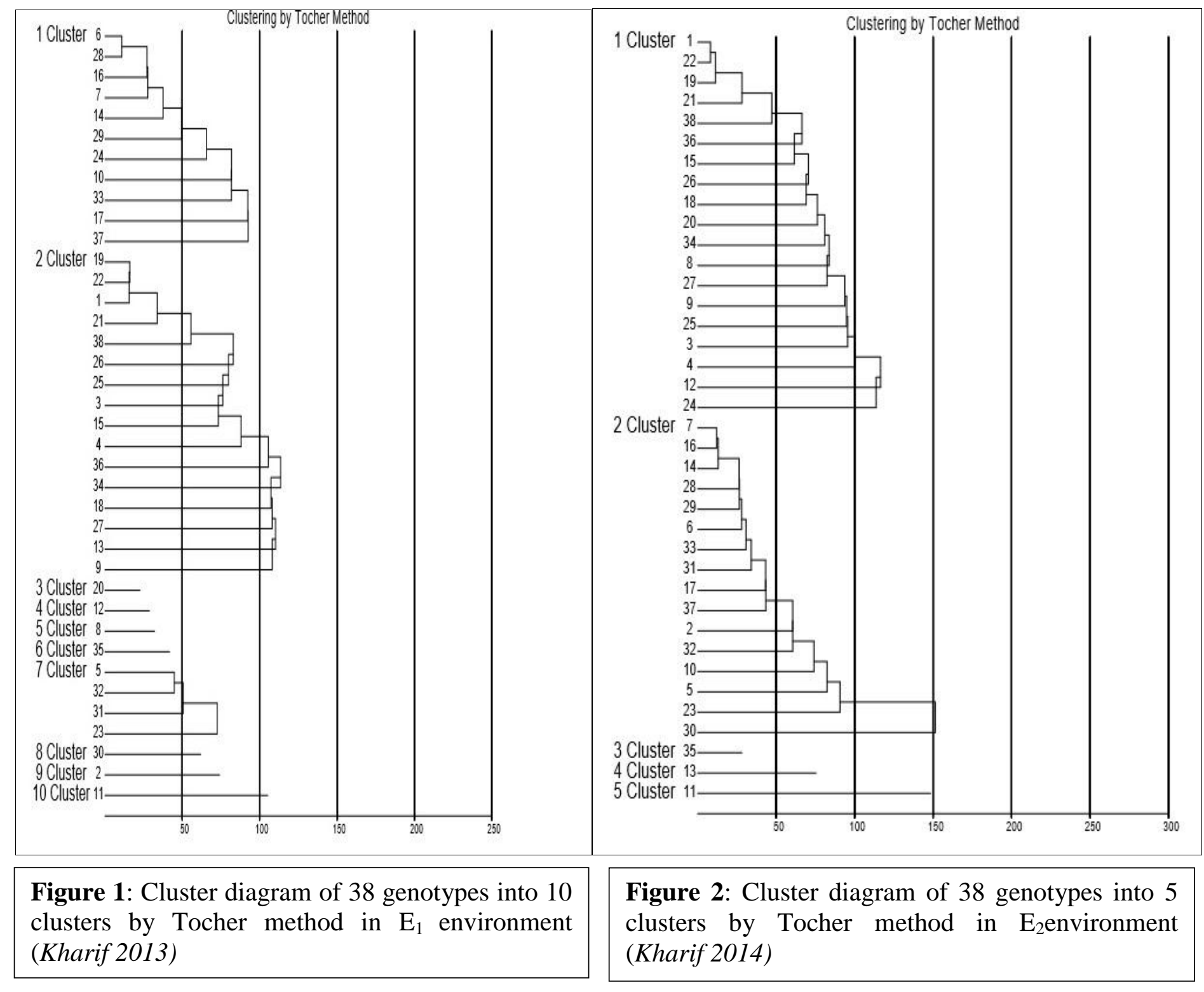


In $E_{2}$ environment the maximum inter-cluster distance $(D=26.18)$ was found between cluster II and III, followed by that between II and V $(\mathrm{D}=25.83)$. The minimum inter-cluster distance was observed between cluster I and IV $(\mathrm{D}=12.42)$. The intra-cluster distance (D) ranged from 8.69 (cluster II) to 9.78 (clusterI). The three clusters (III, IV and V) contained single genotype each having their intra-cluster distances zero. The genotypes grouped into same cluster displayed the lowest degree of divergence from one another. The transgressive segregants are not expected from the cross combinations which are made between genotypes belonging to the same cluster. Therefore, hybridization programmes should always be formulated in such a way that the parents belonging to different clusters with maximum divergence to get desirable transgressive segregants. The genotypes with high values of seed yield and its component traits in any cluster can be used either for direct adoption or for hybridization, followed by selection. These results of genetic diversity study were in accordance with the finding of Valarmathi et al., (2007), Pandey (2007), Suganthi et al., (2007), Dalsaniya et al., (2009), Nagalakshmi et al., (2010), Brahmaiah et al., (2014), Sandeep et al., (2014), Vavilapalli et al., (2014), Aswathi et al., (2015), Chandrakar et al., (2016b) and Patel et al., (2017).

Wide ranges of mean values among the clusters were recorded for different traits in both the environments Table 4. In $\mathrm{E}_{1}$ environment, Cluster VII had the genotype with the highest mean value for number of seed yield per plant, number of pods per plant and number of clusters per plant. Cluster $\mathrm{X}$ recorded maximum mean value for 100 seed weight and cluster IX had highest mean value for number of seeds per pod, while pod length was maximum in cluster III. Cluster IX had maximum mean value for peduncle length and plant height. Cluster IV had maximum branches per plant. In Environment $\mathrm{E}_{2}$, cluster I had the genotypes which showed maximum mean value for seed yield per plant, number of pods per plant, peduncle length, and number of clusters per plant. Cluster II recorded maximum mean value for seeds per pod and plant height, while pod length was maximum in cluster III. The genotype of cluster IV showed maximum mean value for 100 seed weight and number of branches per plant. The results obtained in the present study are in accordance to the findings of Brahmaiah et al., (2014), Vavilapalli et al., (2014), Chandrakar et al., (2016b) and Patel et al., (2017).

In the present diversity analysis it was concluded that the genotypes from most diverse groups $i$. $e$. cluster VII and cluster X in $E_{1}$ environment and cluster II and cluster III in $\mathrm{E}_{2}$ environment having high seed yield per plant could be utilized in selection of parents for crossing and deciding the best cross combinations which may generate the highest possible variability for various studied traits.

\section{References}

Aswathi, C., Devadas, V.S., Francies, R. M. and Bastian, D. 2015. Genetic divergence in cowpea (Vigna spp.) varieties for seed quality. Journal of Tropical Agriculture, 53(2): 197-199.

Brahmaiah, M., Jhansi R. K., Sunil N. and Keshavulu K. 2014.Genetic divergence in cowpea (Vigna unguiculata (L.) Walp) for yield components and seed quality parameters. Electronic Journal of Plant Breeding, 5(1): 107-111.

Chandrakar, R., Verma, A., Singh, J. and Mehta, N. 2016a.Genetic divergence in vegetable cowpea (Vigna unguiculata L.).The Asian Journal of Horticulture. 11(2): 323-328. 
Chandrakar, R., Verma, A., Singh, J. and Mehta, N. 2016b. Studies on genetic divergence in vegetable cowpea (Vigna unguiculata L.). International Journal of Agriculture Sciences, 8(63): 35453547.

Dalsaniya, S.B., Poshiya, V.K., Savaliya, J.J., Pansuriya, A.G. and. Davada, B.K. 2009. Genetic divergence in cowpea [Vigna unguiculata (L.) walp.]. Legume Res., 32(4): 250-254.

Mahalanobis, P. C. 1936. On the generalized distance in statistics. Proc. Natl. Inst. Sci. India.2: 49-55.

Nagalakshmi, R. M., Usha Kumari, R. and Boranayaka, M. B. 2010.Assessment of genetic diversity in cowpea (Vigna unguiculata). Electronic Journal of Plant Breeding, 1(4): 453-461.

Pandey, I. 2007. Genetic diversity in grain cowpea (Vigna unguiculata (L.) walp). Legume Res., 30(2): 92-97.

Patel, U.V., Parmar, V.K., Tandel, Y.N. and Patel, H.R. 2017. Genetic divergence in cowpea (Vigna unguiculata (L.) Walp.) for yield components parameters. Electronic Journal of Plant Breeding, 8(1): 331-335.
Rao, C.R. 1952.Advanced Statistical Methods in Biometric Research. John Wiley and Sons, Inc. New York. pp. 390.

Sandeep, V., Hemalatha, V., Shashi, B. D. and Swarnalatha, V. 2014. Studies on genetic diversity in Indian cowpea (Vigna unguiculata (L.) Walp) germplasm. International Journal of Plant, Animal and Environmental Sciences. 4(3): 177-180.

Suganthi, S., Murugan, S. and Venkatesan, M. 2007. $\mathrm{D}^{2}$ analysis in cowpea (Vigna unguiculata (L.) Walp.). Legume Res., 30 (2): 145-147.

Valarmathi, G., Surendran, C. and Muthiah, A.R. 2007. Genetic divergence analysis in subspecies of cowpea (Vigna unguiculata ssp. Unguiculata and Vigna unguiculata ssp. Sesquipedalis). Legume Res., 30 (3): 192 - 196.

Vavilapalli, S. K., Celine V.A., Vahab A.M. 2014. Genetic divergence analysis in vegetable Cowpea (Vigna unguiculata subsp. unguiculata (L.)) genotypes. Legume Genomics and Genetics, 5(2): 4-6.

\section{How to cite this article:}

Om Vir Singh, Neelam Shekhawat, Kartar Singh and Gowthami, R. 2018. Genetic Divergence Studies in Cowpea [Vigna unguiculata (L.) Walp.] Germplasm using Mahalanobis D ${ }^{2}$ Analysis. Int.J.Curr.Microbiol.App.Sci. 7(03): 2616-2624. doi: https://doi.org/10.20546/ijcmas.2018.703.302 